\title{
Penelitian Formal Bukti Pemenuhan Kewajiban Penyetoran Pajak Penghasilan Final Pengalihan Hak atas Tanah dan/atau Bangunan
}

\section{Formal Research on Evidence of Fulfillment of Final Income Tax Payment Obligations on Transfer of Rights to Land and/or Buildings}

\author{
Vivian Lora* \& Bastari Mathon \\ Program Studi Magister Kenotariatan, Fakultas Hukum, Universitas Sumatera Utara, Indonesia \\ *Coresponding Email: vivianlora.ssl@gmail.com
}

\begin{abstract}
Abstrak
Artikel ini bertujuan untuk mengetahui proses dan gambaran mengenai ketentuan Penelitian Formal serta sekaligus menganalisa pertanggungjawaban Notaris/PPAT apabila timbul kurang bayar PPh Final PHTB. Masalah difokuskan pada peraturan mengenai Penelitian Formal. Guna mendekati masalah ini dipergunakan metode yuridis normatif yaitu menggambarkan, menelaah, dan menganalisis peraturan mengenai Penelitian Formal dan dianalisis secara kualitatif. Kajian ini menyimpulkan bahwa dalam hal terjadi kurang bayar pajak akibat kebenaran harga transakasi yang dicantumkan pada Surat Pernyataan PHTB maka pertanggungjawaban dibebankan kepada Wajib Pajak dan Penanggung Pajak karena kebenaran harga transaksi bukan merupakan tanggung jawab Notaris/PPAT. Kegiatan penelitian formal mengakibatkan penandatanganan akta menjadi tertunda karena penandatanganan akta tidak dapat dilaksanakan sebelum terbit Surat Keterangan Penelitian Formal.

Kata Kunci: Penelitian Formal; Pajak Penghasilan Final; Pengalihan Hak atas Tanah dan/atau Bangunan.
\end{abstract}

\begin{abstract}
This article or article aims to find out the process and description of the provisions of Formal Research and at the same time analyze the liability of a Notary/PPAT if there is an underpayment of PHTB Final PPh. The problem is focused on regulations regarding Formal Research. In order to approach this problem, a normative juridical method is used, namely describing, analyzing, and analyzing the regulations regarding Formal Research and analyzed qualitatively. This study concludes that in the event of an underpayment of taxes due to the correctness of the transaction price stated in the PHTB Statement Letter, the responsibility is borne by the Taxpayer and the Tax Insurer because the correctness of the transaction price is not the responsibility of the Notary/PPAT. Formal research activities cause the signing of the deed to be delayed because the signing of the deed cannot be carried out before the issuance of the Formal Research Certificate.

Keywords: Formal Investigation; Payment for Final Income Tax; Land and/or Building Ownership Rights Transfer.
\end{abstract}

How to Cite: Lora, V \& Mathon, B. (2021). Penelitian Formal Bukti Pemenuhan Kewajiban Penyetoran Pajak Penghasilan Final Pengalihan Hak atas Tanah dan/atau Bangunan. Jurnal Mercatoria, 14 (1): 29-37. 


\section{PENDAHULUAN}

Pajak adalah iuran rakyat kepada kas negara berdasarkan undang-undang (yang dapat dipaksakan) dengan tiada mendapat jasa timbal (kontra prestasi) yang langsung dapat ditunjukkan dan yang digunakan untuk membayar pengeluaran umum (Mardiasmo, 2003). Membayar pajak merupakan bentuk partisipasi setiap warga negara terhadap pembiayaan negara dan pembangunan nasional (Surjoputro, 2009).

Secara garis besar, Suandy mengemukakan pendapatnya mengenai dua fungsi pajak yaitu (Naharto \& Tjondro, 2014):

1. Pajak berfungsi sebagai finansial (budgeter). Pada fungsi finansial, pajak berfungsi untuk memasukkan uang sebanyak-banyaknya ke kas Negara agar tujuan negara dalam membiayai pengeluaran-pengeluaran negara dapat terpenuhi. Dengan meningkatnya pemasukan uang ke kas negara maka penerimaan negara akan perpajakan juga ikut meningkat.

2. Pajak berfungsi mengatur (regulerend). Pada fungsi ini, pajak berperan sebagai alat untuk mengatur masyarakat dalam bidang ekonomi, sosial, dan politik.

Dalam kegiatan PHTB mengakibatkan munculnya pajak terutang bagi para pihak yaitu Pajak Penghasilan Final (PPh Final) (Pasal 4 ayat 2 Undang-undang Republik Indonesia Nomor 36 Tahun 2008 tentang Perubahan Keempat atas Undang-undang Nomor 7 Tahun 1983 tentang Pajak Penghasilan) yang dikenakan kepada pihak yang menyerahkan/memindahkan haknya atas tanah dan/atau bangunan karena pihak tersebut dianggap mendapatkan suatu imbalan ataupun keuntungan dari PHTB dan Bea Perolehan Hak atas Tanah dan/atau Bangunan (BPHTB) (Pasal 85 ayat 1 Undang-undang Republik Indonesia Nomor 28 Tahun 2009 tentang Pajak Daerah dan Retribusi Daerah) yang dikenakan kepada pihak yang menerima PHTB tersebut.
Ruang lingkup PHTB yang dibahas dalam penelitian ini hanya bagi Wajib Pajak dalam negeri antara: a) Pribadi dengan pribadi; b) Pribadi dengan badan hukum; c) Badan hukum dengan badan hukum; d) Badan hukum dengan pribadi.

Pengenaan PPh Final PHTB diatur berdasarkan Pasal 4 ayat 2 Undangundang Republik Indonesia Nomor 36 Tahun 2008 tentang Perubahan Keempat atas Undang-undang Nomor 7 Tahun 1983 tentang Pajak Penghasilan, kemudian ditegaskan kembali pada Pasal 1 ayat 1 Peraturan Pemerintah Republik Indonesia Nomor 34 Tahun 2016 tentang Pajak Penghasilan atas Penghasilan Dari PHTB, dan Perjanjian Pengikatan Jual Beli atas Tanah dan/atau Bangunan Beserta Perubahannya dan diatur juga dalam Pasal 1 ayat 1 Peraturan Menteri Keuangan Republik Indonesia Nomor 261/PMK.03/2016 tentang Tata Cara Penyetoran, Pelaporan, dan Pengecualian Pengenaan Pajak Penghasilan atas Penghasilan Dari PHTB, dan Perjanjian Pengikatan Jual Beli Atas Tanah dan/atau Bangunan Beserta Perubahannya serta diatur dalam Peraturan Direktur Jenderal Pajak Nomor PER-26/PJ/2018 tentang Perubahan atas Peraturan Direktur Jenderal Pajak Nomor PER-18/PJ/2017 tentang Tata Cara Penelitian Bukti Pemenuhan Kewajiban Penyetoran Pajak Penghasilan atas Penghasilan dari PHTB dan Perjanjian Pengikatan Jual Beli atas Tanah dan/atau Bangunan Beserta Perubahannya.

$\mathrm{PPh}$ Final menganut sistem self assessment yang tercermin dalam Pasal 12 ayat 1 Undang-undang Republik Indonesia Nomor 6 Tahun 1983 tentang Ketentuan Umum Perpajakan yang telah diubah dengan Undang-undang Republik Indonesia Nomor 16 Tahun 2009 dimana setiap Wajib Pajak diberi kepercayaan untuk menghitung dan membayar besaran pajak yang terutang secara benar dan sesuai dengan ketentuan peraturan perundang-undangan perpajakan dan 
tidak menggantungkan pada adanya Surat Ketetapan Pajak, yang mana bertentangan dengan Pasal 3 ayat 5 Peraturan Pemerintah Republik Indonesia Nomor 34 Tahun 2016; Pasal 3 ayat 7 Peraturan Menteri Keuangan Republik Indonesia Nomor 261/PMK.03/2016; dan Pasal 5 Peraturan Direktur Jenderal Pajak Nomor PER-18/PJ/2017 yang telah diubah dengan Peraturan Direktur Jenderal Pajak Nomor PER-26/PJ/2018 bahwa atas Pajak Penghasilan yang dibayarkan wajib melewati proses penelitian bukti pemenuhan kewajiban penyetoran Pajak Penghasilan.

Peraturan Direktur Jenderal Pajak Nomor PER-18/PJ/2017 sebagaimana telah diubah dengan Peraturan Direktur Jenderal Pajak Nomor PER-26/PJ/2018, menyebutkan apabila PPh Final atas PHTB tersebut telah dibayarkan oleh orang pribadi atau badan, maka akan dilanjutkan dengan penelitian bukti pemenuhan kewajiban penyetoran $\mathrm{PPh}$ Final, salah satunya yaitu penelitian formal (Pasal 2 Peraturan Direktur Jenderal Pajak Nomor PER-26/PJ/2018 tentang Perubahan atas Peraturan Direktur Jenderal Pajak Nomor PER-18/PJ/2017 tentang Tata Cara Penelitian Bukti Pemenuhan Kewajiban Penyetoran Pajak Penghasilan atas Penghasilan dari Pengalihan Hak atas Tanah dan/atau Bangunan dan Perjanjian Pengikatan Jual Beli atas Tanah dan/atau Bangunan Beserta Perubahannya). Untuk keperluan penelitian formal ini, orang pribadi atau badan maupun kuasanya harus menyampaikan permohonan penelitian bukti pemenuhan kewajiban penyetoran PPh Final PHTB ke Kantor Pelayanan Pajak yang wilayah kerjanya meliputi lokasi tanah dan/atau bangunan. Permohonan tersebut dilakukan dengan menggunakan surat permohonan dengan melampirkan salah satunya, Surat Pernyataan PHTB (Lampiran II) untuk permohonan penelitian formal (Pasal 3 ayat 1 Peraturan Direktur Jenderal Pajak Nomor PER26/PJ/2018 tentang Perubahan atas Peraturan Direktur Jenderal Pajak Nomor PER-
18/PJ/2017 tentang Tata Cara Penelitian Bukti Pemenuhan Kewajiban Penyetoran Pajak Penghasilan atas Penghasilan dari Pengalihan Hak atas Tanah dan/atau Bangunan dan Perjanjian Pengikatan Jual Beli atas Tanah dan/atau Bangunan Beserta Perubahannya). Pada akhir Lampiran II tersebut oleh Notaris/PPAT wajib diketahui dan ditandatangani. Oleh sebab itu, apabila data yang diisi pada Lampiran II tersebut salah atau tidak sesuai dengan sebenarnya sehingga menyebabkan kekurangan bayar atas PPh Final PHTB yang terutang, timbul masalah mengenai bagaimana pertanggungjawaban Notaris/PPATatas kekurangan bayar pajak tersebut setelah dilakukannya penelitian formal karena ikut serta mengetahui dan menandatangani Lampiran II tersebut.

Teori pertanggungjawaban oleh Hans Kelsen bahwa "Seseorang individu bertanggung jawab atas pelanggaran yang dilakukan orang lain, individu yang diwajibkan dan yang bertanggung jawab tidaklah identik" (Kelsen, 2008). Teori tersebut untuk menganalisa pertanggungjawaban Notaris/PPAT terhadap kekurangan bayar PPh Final PHTB setelah dilakukan Penelitian Formal.

Kemudian, atas permohonan penelitian formal, akan diterbitkan Surat Keterangan Penelitian Formal Bukti Pemenuhan Kewajiban Penyetoran Pajak Penghasilan apabila terpenuhi kesesuaian data sebagaimana diatur dalam Pasal 4 Peraturan Direktur Jenderal Pajak Nomor PER-18/PJ/2017 sebagaimana telah diubah dengan Peraturan Direktur Jenderal Pajak Nomor PER-26/PJ/2018. Namun, ada kemungkinan Surat Keterangan Penelitian Formal Bukti Pemenuhan Kewajiban Penyetoran Pajak Penghasilan tersebut tidak dapat diterbitkan maka berdasarkan Pasal $4 \mathrm{~A}$ ayat 1 Peraturan Direktur Jenderal Pajak Nomor PER-18/PJ/2017 sebagaimana telah diubah dengan Peraturan Direktur Jenderal Pajak Nomor PER-26/PJ/2018 akan diterbitkan Surat Pemberitahuan 
Permohonan Penelitian Tidak Lengkap dan/atau Tidak Sesuai.

Pejabat yang berwenang yaitu Pembuat Akta Tanah dapat melakukan penandatanganan akta apabila kepadanya dapat diperlihatkan fotokopi bukti pembayaran $\mathrm{PPh}$ Final beserta Surat Keterangan Penelitian Formal Bukti Pemenuhan Pajak Penghasilan. Apabila Surat Keterangan Penelitian Formal Bukti Pemenuhan Pajak Penghasilan tidak diterbitkan akibat ketidaksesuaian data sebagaimana dengan ketentuan diatas ataupun terlambat diterbitkan, maka penandatangan akta tidak dapat dilakukan padahal kewajiban para pihak dalam kegiatan transaksi PHTB telah dipenuhi. Oleh sebab itu, timbul pertanyaan mengenai esensi kepastian hukum bagi para pihak yang melakukan PHTB.

Teori Kepastian yang dikemukakan oleh Radbruch bahwa aspek kepastian menunjuk pada jaminan bahwa hukum benar-benar berfungsi sebagai peraturan yang ditaati, sebagai kerangka operasional hukum (Tanya, 2010). Guna mengetahui esensi kepastian hukum atas beralihnya hak atas tanah dan/atau bangunan dengan diberlakukannya ketentuan Penelitian Formal.

Tujuan penelitian ini adalah untuk mengetahui dan menganalisis gambaran mengenai ketentuan Penelitian Formal Bukti Pemenuhan Kewajiban Penyetoran Pajak Penghasilan Final Pengalihan Hak atas Tanah dan/atau Bangunan; Untuk memahami sekaligus menganalisa pertanggungjawaban Notaris/Pejabat Pembuat Akta Tanah terhadap kekurangan bayar Pajak Penghasilan Final Pengalihan Hak atas Tanah dan/atau Bangunan setelah dilakukan Penelitian Formal Bukti Pemenuhan Penyetoran Pajak Penghasilan Final Pengalihan Hak atas Tanah dan/atau Bangunan.; dan Untuk mengetahui dan menganalisis esensi kepastian hukum atas beralihnya hak atas tanah dan/atau bangunan dengan diberlakukannya Penelitian Formal Bukti Pemenuhan
Kewajiban Penyetoran Pajak Penghasilan Final dari Pengalihan Hak atas Tanah dan/atau Bangunan.

\section{METODE PENELITIAN}

Jenis penelitian dalam Penelitian ini menggunakan metode yuridis nomatif atau disebut juga dengan penelitian kepustakaan yang bersifat deskriptif (Soekanto, 1986) yaitu dengan menggambarkan, menelaah, menjelaskan dan menganalisis suatu peraturan hukum terkait dengan Penelitian Formal. Penelitian hukum normatif juga memiliki kecenderungan dalam mencitrakan hukum sebagai disiplin perspektif dimana hanya melihat hukum dari sudut pandang normanormanya saja, yang tentunya bersifat perskriptif (Sonata, 2014).

\section{HASIL DAN PEMBAHASAN}

Dasar hukum penerapan pemungutan pajak di Indonesia adalah ketentuan yang terdapat dalam Pasal 23 A Undang-undang Dasar Negara Republik Indonesia Tahun 1945 yaitu menyatakan bahwa semua pajak untuk keperluan negara berdasarkan undangundang.

Pengertian penghasilan itu sendiri adalah setiap tambahan kemampuan ekonomis yang berasal baik dari Indonesia maupun luar Indonesia yang dapat digunakan untuk konsumsi atau untuk menambah kekayaan dalam bentuk apapun (Sukmawati, Budiono, \& Nurdin, 2016).

Orang pribadi atau badan yang menerima atau memperoleh penghasilan dari Pengalihan Hak atas Tanah dan/atau Bangunan menyetor sendiri Pajak Penghasilan yang terutang (Pasal 3 ayat 1 Peraturan Menteri Keuangan Republik Indonesia Nomor 261/PMK.03/2016 tentang Tata Cara Penyetoran, Pelaporan, dan Pengecualian Pengenaan Pajak Penghasilan atas Penghasilan dari Pengalihan Hak atas Tanah dan/atau Bangunan, dan Perjanjian Pengikatan Jual Beli atas Tanah dan/atau Bangunan Beserta Perubahannya). Artinya orang pribadi atau badan diberi kewenangan untuk menentukan sendiri 
nilai Pajak Penghasilan yang terutang. Sistem pemajakan ini dikenal dengan sistem self assessment.

Adapun beberapa sistem pemungutan pajak yang dikenal selain sistem self assessment, yaitu (Zaimah, 2016):

a. Sistem Official Assessment. Sistem pemungutan pajak yang memberi wewenang kepada pemungut pajak untuk menentukan besarnya pajak yang harus dibayar oleh seseorang.

b. Sistem Semi Self Assessment. Sistem pemungutan pajak yang memberi wewenang kepada fiskus dan wajib pajak untuk menentukan besarnya pajak seseorang yang terutang.

c. Sistem Withholding. Sistem pemungutan pajak yang memberi wewenang kepada pihak ketiga untuk memotong ataupun memungut besarnya pajak yang terutang. Selanjutnya, pihak ketiga yang telah dilakukan akan berperan untuk menyetor dan melaporkannya kepada fiskus.

Jelas bahwa Pajak Penghasilan di Indonesia menganut sistem self assessment. Dimana Wajib Pajak memiliki tanggung jawab untuk menghitung, menyetor, dan melaporkan sendiri Pajak Penghasilannya. Sedangkan, pemerintah bertugas untuk mengawasi pelaksanaan sistem self assessment. Melihat hal tersebut, kepatuhan wajib pajak menjadi aspek penting sehingga penerimaan pajak dapat menjadi optimal (Widodo, 2010).

Salah satu berkas yang wajib dilampirkan atas permohonan penelitian formal tersebut merupakan Surat Pernyataan PHTB yang wajib diketahui dan ditandatangani oleh Notaris/PPAT sebagaimana diatur dalam Lampiran II Peraturan Direktur Jenderal Pajak Nomor PER-18/PJ/2017 yang telah diubah dengan Peraturan Direktur Jenderal Pajak Nomor PER-26/PJ/2018. Hal tersebut tidak sesuai dengan Undang-undang Jabatan Notaris dan Peraturan Pemerintah tentang PPAT. Di sisi lain, dalam Surat Pernyataan PHTB mewajibkan juga untuk mengisi mengenai informasi atas kegiatan PHTB seperti identitas para pihak, letak objek, harga transaksi, dan lain sebagainya. Dapat saja terjadi mengenai harga transaksi PHTB yang sebenarnya, diketahui lebih tinggi atau lebih besar dari harga transaksi yang dicantumkan pada Surat Pernyataan PHTB. Dampak keadaan perpajakan yang demikian akan mengakibatkan timbulnya kekurangan bayar PPh Final atas PHTB. Adapun mengenai kekurangan bayar atas PPh Final dari kegiatan PHTB setelah dilakukannya penelitian formal yang diketahui oleh Direktorat Jenderal Pajak baik melalui proses penelitian maupun pemeriksaan.

Apabila diketahui dari hasil pemeriksaan, oleh Pasal 13 ayat $1 \mathrm{~A}$ Undang-undang Nomor 28 Tahun 2007 tentang Perubahan Ketiga atas Ketentuan Umum dan Tata Cara Perpajakan maka akan diterbitkan Surat Ketetapan Pajak Kurang Bayar. Pada Pasal 13 tersebut ayat 3 menyebutkan jumlah pajak yang harus dibayar adalah kekurangan jumlah $\mathrm{PPh}$ Final yang terutang sebagaimana dicantumkan pada Surat Ketetapan Pajak Kurang Bayar ditambah dengan sanksi administrasi berupa kenaikan sebesar: $50 \%$ (lima puluh persen) dari Pajak Penghasilan yang tidak atau kurang dibayar dalam satu Tahun Pajak; 100\% (seratus persen) dari Pajak Penghasilan yang tidak atau kurang dipotong, tidak atau kurang dipungut, tidak atau kurang disetor, dan dipotong atau dipungut tetapi tidak atau kurang disetor.

Sedangkan, apabila kekurangan bayar diketahui melalui proses penelitian, maka berdasarkan Pasal 14 ayat 1 Undang-undang Nomor 28 Tahun 2007 tentang Perubahan Ketiga atas Ketentuan Umum dan Tata Cara Perpajakan atas kekurangan bayar PPh Final tersebut akan diterbitkan Surat Tagihan Pajak.

Maka, jumlah pajak yang harus dibayar sesuai dengan Pasal 13 ayat 3 
Undang-undang Ketentuan Umum dan Tata Cara Perpajakan adalah jumlah PPh Final terutang yang kurang dibayar ditambah dengan sanksi administrasi berupa bunga sebesar 2\% (dua persen) per bulan untuk paling lama 24 (dua puluh empat) bulan, dihitung sejak saat terutangnya pajak atau berakhirnya masa pajak, bagian tahun pajak, atau tahun pajak sampai dengan diterbitkannya Surat Tagihan Pajak.

Walaupun Notaris/PPAT ikut mengetahui dan menandatangani Surat Pernyataan PHTB, ia tidak dapat dimintakan pertanggungjawaban karena ia bukan Wajib Pajak. Hal ini berdasarkan pada Pasal 1 angka 2 Undang-undang Ketentuan Umum dan Tata Cara Perpajakan, bahwa Wajib Pajak adalah orang pribadi atau badan, meliputi pembayar pajak, pemotong pajak yang mempunyai hak dan kewajiban perpajakan sesuai dengan ketentuan peraturan perundang-undangan perpajakan.

Selain Wajib Pajak, adapun pihak lain yang dapat dimintakan pertanggungjawaban adalah Penanggung Pajak. Berdasarkan Pasal 1 angka 28 Undang-undang Ketentuan Umum dan Tata Cara Perpajakan, Penanggung Pajak adalah orang pribadi atau badan yang bertanggungjawab atas pembayaran pajak, termasuk wakil yang menjalankan hak dan memenuhi kewajiban Wajib Pajak sesuai dengan ketentuan peraturan perundangundangan perpajakan. Melalui penjelasan tersebut diketahui bahwa Notaris/PPAT juga tidak tergolong sebagai Penanggung Pajak.

Pertanggungjawaban

seorang

Notaris/Pejabat Pembuat Akta Tanah akan muncul apabila perbuatan yang dilakukannya melanggar hukum (onrechtmatigedaad) dan merupakan penyebab (oorzaak) dari timbulnya kerugian (Adiansyah, 2018).

Peralihan atau pemindahan hak adalah sesuatu hal yang menyebabkan hak atas tanah berpindah atau beralih dari seseorang/badan hukum kepada orang lain/badan hukum, maka dengan dialihkannya suatu hak menunjukkan adanya suatu perbuatan hukum yang disengaja dilakukan oleh satu pihak dengan maksud memindahkan hak miliknya kepada orang lain (Pulungan \& Muazzul, 2017).

Menurut Salim HS, ia berpendapat bahwa akta otentik sebagai suatu tanda bukti yang dibuat oleh/atau dihadapan pejabat yang berwenang untuk itu, menurut bentuk dan tata cara yang ditetapkan dalam peraturan perundangundangan (HS, 2016).

Apabila konsep akta otentik dimaknai dalam arti perundang-undangan, maka dapat dikatakan bahwa semua akta yang dikeluarkan oleh pejabat publik, yang menurut peraturan perundang-undangan berwenang membuat akta itu adalah akta otentik (Iryadi, 2018). Maka fungsi akta disini dalam kegiatan Pengalihan Hak atas Tanah dan/atau Bangunan yaitu sebagai alat bukti kuat atas perbuatan hukum Pengalihan Hak atas Tanah dan/atau Bangunan.

Menurut Fence M. Wantu, "hukum tanpa nilai kepastian hukum akan kehilangan makna karena tidak lagi dapat dijadikan pedoman perilaku bagi semua orang" (Wantu, 2007). Kepastian hukum diartikan sebagai kejelasan norma sehingga dapat dijadikan pedoman bagi masyarakat yang dikenakan peraturan ini. Pengertian kepastian tersebut dapat dimaknai bahwa ada kejelasan dan ketegasan terhadap berlakunya hukum di dalam masyarakat, yang mana menimbulkan banyak salah penafsiran (Prayogo, 2016).

Hal tersebut sejalan dengan pendapat Van Apeldoorn bahwa kepastian hukum memiliki dua segi yaitu hukum dalam keadaan hal yang konkret dan keamanan hukum. Hal disini berarti bahwa pihak yang mencari keadilan tersebut ingin mengetahui apa yang menjadi hukum dalam suatu hal tertentu sebelum ia memulai suatu perkara dan bertindak 
sebagai perlindungan bagi para pencari keadilan (Julyano, 2019).

Kepastian hukum dapat diartikan juga sebagai kejelasan norma sehingga dapat dijadikan pedoman bagi masyarakat agar tidak menimbulkan perbedaan tafsir dalam suatu peraturan yang belaku di dalam masyarakat (Wijayanata, 2014).

Pasal 3 ayat 1 Peraturan Pemerintah Republik Indonesia Nomor 34 Tahun 2016 mewajibkan penyetoran Pajak Penghasilan terlebih dahulu sebelum melakukan penandatanganan akta. Sementara itu, di sisi lain, menurut Pasal 5 Peraturan Direktur Jenderal Pajak Nomor PER18/PJ/2017 yang telah diubah dengan Peraturan Direktur Jenderal Pajak Nomor PER-26/PJ/2018, meskipun Pajak Penghasilan telah disetorkan, penandatangan akta belum dapat dilakukan karena perlu menunggu hingga diterbitkannya Surat Keterangan Penelitian Formal Bukti Pemenuhan Kewajiban Penyetoran Pajak Penghasilan.

Menurut bunyi Pasal 4 ayat 2 A Peraturan Direktur Jenderal Pajak Nomor PER-18/PJ/2017 yang telah diubah dengan Peraturan Direktur Jenderal Pajak Nomor PER-26/PJ/2018, jangka waktu dari permohonan penelitian formal hingga diterbitkannya Surat Keterangan Penelitian Formal Bukti Pemenuhan Kewajiban Penyetoran Pajak Penghasilan adalah: paling lama 3 (tiga) hari kerja dihitung dari permohonan Penelitian Formal. Akibat adanya jangka waktu paling lama 3 (tiga) hari tersebut, penandatanganan akta tidak dapat langsung segera dilakukan padahal harga transakasi PHTB telah dilunasi dan $\mathrm{PPh}$ Final atas PHTB juga telah dibayarkan.

Semestinya, beralihnya hak atas dan/atau bangunan sudah terjadi setelah adanya pelunasan dari harga jual beli, kemudian para pihak baik penjual maupun pembeli telah menyetorkan PPh Final dan Bea Perolehan Hak atas Tanah dan/atau Bangunan. Namun, secara formil beralihnya hak atas tanah dan/atau bangunan wajib dibuktikan dengan penandatanganan akta otentik.

Kedudukan akta yang dibuat dihadapan PPAT merupakan bukti telah dilaksanakannya perbuatan hukum tertentu yaitu PHTB.

Apabila salah satu pihak antara penjual atau pembeli meninggal dunia pada hari sebelum dilakukannya penandatanganan akta akibat menunggu proses penelitian formal, maka kepastian hukum PHTB disini menjadi kabur padahal harga PHTB dan PPh Final telah dilunasi.

Tidak hanya itu, mengenai batas waktu penelitian formal yang paling lama 3 (tiga) hari tersebut, tidak ada pengaturan lebih lanjut tentang resiko dan akibat hukum apabila dalam jangka waktu 3 (tiga) hari tersebut Surat Keterangan Penelitian Formal Bukti Pemenuhan Kewajiban Penyetoran Pajak Penghasilan belum diterbitkan. Mengenai permohonan Penelitian Formal ditolak maka akan diterbitkan Surat Pemberitahuan Permohonan Tidak Lengkap dan/atau Tidak Sesuai dalam jangka waktu paling lama 3 (tiga) hari. Kemudian untuk diajukan kembali permohonan penelitian formal, alhasil membutuhkan waktu lebih dari 3 (tiga) hari kerja. Hal ini memungkinkan kegiatan penelitian formal akan memakan jangka waktu lebih dari 3 (tiga) hari hingga seminggu maupun berbulan.

\section{SIMPULAN}

Notaris/PPAT yang ikut mengetahui dan menandatangani Surat Pernyataan PHTB tidak bertanggung jawab atas kekurangan bayar PPh Final PHTB karena pertanggungjawaban atas kekurangan bayar pajak dibebankan kepada Wajib Pajak dan Penanggung Pajak. Sedangkan, Notaris/PPAT tidak tergolong sebagai Wajib Pajak maupun Penanggung Pajak. Notaris/PPAT seharusnya tidak perlu ikut menandatangani Surat Pernyataan PHTB sebagaimana diatur dalam Lampiran II Peraturan Direktur Jenderal Pajak Nomor 
PER-18/PJ/2017 yang telah diubah dengan Peraturan Direktur Jenderal Pajak Nomor PER-26/PJ/2018, karena mengenai kebenaran harga PHTB bukan merupakan tanggung jawab seorang Notaris/PPAT.

Kepastian hukum mengenai beralihnya hak atas tanah dan/atau bangunan karena adanya penelitian formal menjadi tertunda. Hal ini dikarenakan, penandatanganan akta tidak dapat dilaksanakan sebelum penelitian formal dilaksanakan dan diterbitkannya Surat Keterangan Penelitian Formal Bukti Pemenuhan Kewajiban Penyetoran Pajak Penghasilan padahal akta itu sendiri berperan sebagai kepastian hukum bukti yang kuat atas perbuatan hukum PHTB.

Kantor Pelayanan Pajak yang wilayah kerjanya meliputi lokasi tanah dan/atau bangunan hendaknya mempercepat proses pelayanan penelitian formal dengan sistem one-day service sehingga tidak menghambat kegiatan penandatanganan akta.

Sesuai dengan sistem self assessment pada Pajak Penghasilan, maka ketentuan pada Lampiran II dan Pasal 4 ayat 2 pada Peraturan Direktur Jenderal Pajak Nomor PER-18/PJ/2017 yang telah diubah dengan Peraturan Direktur Jenderal Pajak Nomor PER-26/PJ/2018, mengenai harga transaksi dan jumlah Pajak Penghasilan pada Lampiran II tersebut seharusnya dihilangkan, karena apabila kedua hal tersebut bermasalah maka akan menunda proses penandatanganan akta yang memberikan kepastian hukum. Disamping itu, ketentuan tentang batas waktu penerbitannya perlu direvisi, hendaknya diberikan juga kepastian mengenai akibat hukum apabila Surat Keterangan Penelitian Formal Bukti Pemenuhan Kewajiban Penyetoran Pajak Penghasilan belum diterbitkan hingga melewati jangka waktu sebagaimana diatur maka dianggap telah diterbitkan.

\section{DAFTAR PUSTAKA}

Adiansyah, H. (2018). Tanggung Gugat Notaris Atas Ketidaksesuaian Harga Transaksi Jual Beli
Tanah dan Bangunan Dengan Harga Sebenarnya. Jurnal Hukum Magister Kenotariatan Universitas Narotama Surabaya , 60.

HS, S. (2016). Teknik Pembuatan Akta Satu; Konsep Teoritis, Kewenangan Notaris, Bentuk dan Minuta Akta. Jakarta: Rajawali Pers.

Iryadi, I. (2018). Kedudukan Akta Otentik Dalam Hubungannya Dengan Hak Konstitusional Warga Negara. Jurnal Konstitusi : Program Doktor Ilmu Hukum Universitas Diponegoro, 15 (4), 806.

Julyano, M. (2019). Pemahaman Terhadap Asas Kepastian Hukum Melalui Konstruksi Penalaran Positivisme Hukum. Jurnal Crepido, 2019), hal 14., 1 (1), 14.

Kelsen, H. (2008). Teori Hukum Murni Dasar-Dasar Ilmu Hukum Normatif. Bandung: Nusa Media.

Mardiasmo. (2003). Perpajakan. Yogyakarta: Andi Offset.

Naharto, M. J., \& Tjondro, E. (2014). Analisis Tujuan Pemungutan Serta Pengertian Penghasilan Menurut Perpajakan Dan Persepuluhan Bagi Wajib Pajak Orang Pribadi. Tax \& Accounting Review, 4 (1), 4.

Prayogo, R. (2016). Penerapan Asas Kepastian Hukum Dalam Peraturan Mahkamah Angung Nomor 1 Tahun 2011 tentang Hak Uji Materiil dan dalam Peraturan Mahkamah Konstitusi tentang Pedoman Beracara dalam Pengujian Undang-undang. Jakarta: Direktorat Jenderal Peraturan Perundang-undangan Kementerian Hukum dan HAM.

Pulungan, T., \& Muazzul. (2017). Tinjauan Hukum Tentang Peralihan Hak Atas Tanah Melalui Perjanjian Gadai Di Bawah Tangan. Jurnal Ilmiah Penegakan Hukum, 2017, 62.

Soekanto, S. (1986). Pengantar Penelitian Hukum. Jakarta: UI Press.

Sonata, D. L. (2014). Metode Penelitian Hukum Normatif dan Empiris : Karakteristik Khas Dari Metode Meneliti Hukum. , Volume 8 No.1, (Lampung : Fiat Justisia Jurnal Ilmu Hukum, 2014), hal 25., 8 (1), 25.

Sukmawati, F. D., Budiono, A. R., \& Nurdin. (2016). Pembayaran Pajak Penghasilan (PPh) Dan Bea Perolehan Hak Atas Tanah Dan Atau Bangunan (BPHTB) Dalam Pengalihan Hak Atas Tanah Dan Atau Bangunan. Jurnal Hukum , 20.

Surjoputro, D. S. (2009). Buku Panduan Hak dan Kewajiban Wajib Pajak. Jakarta: Direktorat Penyuluhan Pelayanan dan Humas.

Tanya, B. L. (2010). Teori Hukum Strategi Tertib Manusia Lintas Ruang dan Generasi. Yogyakarta: Genta Publishing.

Wantu, F. M. (2007). Antinomi Dalam Penegakan Hukum Oleh Hakim. Jurnal Berkala Mimbar Hukum, 19 (3), 388. 
Widodo, W. (2010). Moralitas, Budaya dan Kepatuhan Pajak. Bandung: Alfabeta.

Wijayanata, T. (2014). Asas Kepastian Hukum, Keadilan, dan Kemanfaatan Dalam Kaitannya Dengan Putusan Kepailitan Pengadilan Niaga. Jurnal Dinamika Hukum, 14 (2), 219.
Zaimah, T. (2016). Efektivitas Sistem Self Assessment Dalam Pajak Penghasilan Di Kantor Pelayanan Pajak Pratama Batu (Perspektif Hukum Positif Dan Hukum Islam). Jurnal Hukum dan Syariah, 7 (1), 47. 